\title{
Financial capital appraisal in the system of industrial enterprise development management
}

\author{
M.K. Akhtyamov ${ }^{1, *}$, and E.A. Gonchar ${ }^{1}$ \\ ${ }^{1}$ South Ural State University, Chelyabinsk, Russia
}

\begin{abstract}
The paper studies an objective appraisal of financial capital value in industrial enterprise development management. The authors draw attention to a limited scope of work in the area of financial management under application of a traditional approach to appraisal of enterprise financial capital value and describe a new advanced approach to this problem solving. The paper focuses on reformation of balance sheet statement, in which economic benefit and reserves of financial capital are included by the authors; the author's methodology for appraisal of financial capital value and its application sphere are denoted. In accordance with a case study, we confirm possibility of more accurate appraisal of enterprise investment opportunities by taking into account economic benefit from reserve of liquidity and borrowing capacity, which increases financial capital value. The practical approval results affirm that application of proprietary methodology for appraisal of financial capital and its elements has practical utility in solving problems of determination of required amount of attracted foreign investments and problems of determination of fair value of company take of an external investor, which are aimed at minimizing risks of corporate ownership dissemination and improving managerial efficiency of an industrial enterprise.
\end{abstract}

\section{Introduction}

Variability of external and internal environment of an industrial enterprise and its complicated predictability determines need to have a flexible management instrumentarium for well-timed stimulating improvement of positive events and prevention of negative one. Top management of an enterprise should quickly and objectively take decisions about financial capital management in the context of solving of subproblem and general problem of current and strategic management of socio-economic development, increasing intrinsic and market value of a company and improving its competitiveness and investment attractiveness. In the field of financial capital management managers have to constantly solve money management issues through regulation of current activities financing, debt fund raising and investment of temporarily free cash, as well as complete tasks of receivables management and inventory control.

All the listed objectives are aimed at improvement of competitiveness, investment attractiveness and level of socio-economic development of industrial enterprise. Addressing these problems is tightly intertwined among themselves. There are occasions in the management practice, when a positive solution to one problem creates a negative result of another problem solving, so rolling valuation of financial capital, appraisal of baseline and forecast cost and assessment of enterprise economic benefit from possession and disposal of idle financial capital are highly sought in order to avoid unplanned failures in achieving current and strategic objectives in industrial enterprise development management.

\section{Timeliness. Scholarly importance}

Financial capital value is traditionally determined on basis of sum of balance sheet assets or their sources or on basis of enterprise net asset value. This approach allows us to solve problem of estimating balance sheet value of property, salvage value of property and carrying value of shares of company founders. It also allows to analyze liquidity, solvability, financial stability, economic activity and borrowing power of a company as well as to determine stockout of current assets and to appraise enterprise debt capacity reserve. However scope of financial management tasks is much wider, and it is impossible to solve them by virtue of these measurements. First of all, this is referred to appraisal and management of intrinsic enterprise value, which elements include financial capital. Management of intrinsic industrial enterprise value is directed at its investment attractiveness improvement, stimulating investment in projects, being developed or implemented. Therefore, appraisal of real cost of intrinsic industrial enterprise value components, including financial capital, plays an important role in this matter. Financial capital is directly involved in intellectual capital formation, transforming in human, organization and innovation capital. Formation of market capital dispenses with financial capital because it promotes customer equity and resource capital. Effective use of financial capital

Corresponding author: a-mavlit@yandex.ru 
has also influence on value of commercial goodwill through achieving satisfactory levels of creditworthiness, fiscal discipline and a partnership of trust. All of these factors indicate importance of real financial capital appraisal in the system of industrial enterprise development management.

Issue of appraisal of enterprise financial capital value has not received due cognisance in science yet.

Most scientists cover a wider aspect of cost, considering the appraisal of company or business, real estate (Aniskin J. P. [9] Shcherbakov V.A., Shcherbakova N. A. [19] Dietger Hahn, Hungenberg Harald [11] Kudrina M. W. [13], Esipov V. E. Makhovikova G. A., Mirzazhanov S. K., Terekhova V. V. [20,21], Rutgaizer V. M. [22] Valdaizev S. V. [ 17], Chernozub O. [14], Jay E. Fishman, Shannon P. Pratt, J. Clifford Griffith, Kate Wilson [10], Cahill G. A., Schneider G. P. [13], Tarasevich E. I. [6,] Black A. [1], Zarev V. V. [23], Volkov D. L. [5], Gribovskii S. V, Ivanova E. N., Lvov D. S., Medvedeva O. E. [16]) and agenda of enterprise value management (including industrial companies): Gershun A., Gorskii M. [2], Nikitushkina I. V. [8] Drogovoz P. A. [15], Beer S. [4].

Nevertheless, in works of these scientists there are presented theories and models of enterprise appraisal, which may be the basis for development of partial models of company value elements appraisal. Among these theories and models are as follows: 1) the theory of economic profit, developed by A. Marshall in the 19 th century; 2) the concept of added value, expressed in models of market value added (MVA) and economic value added (EVA), which are designed to evaluate process of enterprise value creating; 3) model of shareholder value added (SVA) (by A. Rappoport shareholder value added is defined as difference between two indicators: share capital value after a operation and the same capital value before that operation [13]); 4) model of options (models of option price formation can be used in order to apprise any asset with features of option) and so-called "formulary" version of discounted cash flow method (Modigliani-Miller formula, which can be used for determination of company cost sources, is one of the "formulaic" versions); 5) Ellwood model, which is based on valuation of property; 6) model of general mortgage and investment analysis; 7) model of innovation industrial enterprise value formation [15] and others. A. N. Sorokin directly associates cost of capital, as a benchmark, with appraisal of enterprise (business) value, arguing that cost of capital is rate of profit, which an investor expects to receive from his investment, taking into account the risks, associated with it [3]. As Cherutova M. I., Trofimova I. G. and Cherutova O.V. stressed, a level of enterprise capital value is the most important measure of a level of its market value [12]. Varfolomeeva V. A., Ivanova N. A. and Arkhipova I.I. understand cost of capital as income, which is to be reached by investments in order to prove their value from an investor's point of view [18].
According to the authors, under appraisal of capital value it is important to take as point of departure interpretation of its essence as economic benefit, which it may bring to an enterprise, but at the same time different nature of cost components is to be taken into account. Concerning financial capital cost, we should proceed from enterprise economic benefit from ownership and disposal of its invested and free parts. This requires paying attention to features of financial capital appraisal, where financial capital is deemed as a specific integral component of intrinsic enterprise value. Meanwhile, taking into account a wider range of investment opportunities of industrial enterprises, it is advisable to consider this issue in a broad perspective. Therefore, we choose development of methodology for appraisal of industrial enterprise financial capital cost in the context of improving system of industrial enterprise development management as a goal of this paper.

\section{Thesis statement}

For this goal achievement within the context of this paper it is necessary to solve the following problems. Firstly, it is required to present structure of company balance sheet statement with regard to financial capital, demonstrating its scope and economic benefits.

Secondly, it is obligatory to develop a methodology for assessment of enterprise economic benefit from ownership and disposal of free financial capital and a methodology for appraisal of total financial capital cost and appraisal of its growth.

Thirdly, it is important to define application sphere for this methodology for assessment of economic benefit from enterprise ownership and disposal of free financial capital and the methodology for appraisal of total financial capital cost and appraisal of its growth. Finally, practical calculations, confirming focus of author's recommendations on improving industrial enterprise development management, are to be carried out.

\section{Theoretical part}

The suggested by us approach to understanding of financial capital cost as economic benefit from enterprise ownership and disposal of its invested and free parts calls for formation of a separate balance sheet statement in order to reflect structure and changes in financial component of capital (we qualify it as balance sheet statement of financial capital). The requirements, demanded for its drawing up, are as follows.

First of all, balance sheet statement of financial capital is to be made of two parts. The first part should fully comply with the structure of balance sheet in accordance with Russian accounting standards, meaning that it should present reflection of assets of an enterprise and their sources. The second part is to reflect a ratio of economic benefit from 
ownership of free financial capital, which is at the disposal or is possible to be attracted, (in assets) and reserve, increase of financial capital cost from use of available investment alternatives (in liabilities).

Secondly, economic benefit from ownership and disposal of financial capital is to be divided into two types: 1) economic benefit from liquidity reserve; 2) economic benefit from reserve of borrowing capacity.

Thus, the structure of balance sheet statement of financial capital may be elaborated as follows (Table 1).

Table 1. Balance sheet statement of enterprise financial capital.

\begin{tabular}{|c|c|}
\hline Assets (property) & $\begin{array}{c}\text { Liabilities (origin of } \\
\text { property) }\end{array}$ \\
\hline \multicolumn{2}{|c|}{ Accounting data } \\
\hline $\begin{array}{l}\text { Fixed assets } \\
\text { Current assets }\end{array}$ & $\begin{array}{l}\text { Owner's equity } \\
\text { Creditor's equity }\end{array}$ \\
\hline \multicolumn{2}{|c|}{ Economic benefit and financial capital reserves } \\
\hline $\begin{array}{l}\text { Economic benefit from } \\
\text { liquidity reserve } \\
\text { Economic benefit from } \\
\text { reserve of borrowing } \\
\text { capacity }\end{array}$ & $\begin{array}{c}\text { Liquidity reserve } \\
\text { Reserve of borrowing } \\
\text { capacity } \\
\text { Investment growth of } \\
\text { financial capital }\end{array}$ \\
\hline
\end{tabular}

In the next steps we move to development of methodology for evaluation of the items of the second section of the above given balance sheet statement, specifically economic benefit and reserves of enterprise financial capital.

\section{A. Methodology for appraisal of economic benefit from liquidity reserve}

It is commonly known that liquidity should be understood as ability of a company to repay its shortterm obligations (current liabilities) duly at the expense of current (working) assets. There is ratio of absolute, quick and current liquidity. Absolute liquidity means that company is able to repay its short-term liabilities timely due to the most liquid part of assets - cash (some experts also add to them even short-term financial investments). Quick liquidity indicates ability of a company to repay its short-term obligations at the cost of the group of current assets, which includes cash, short-term financial investments and receivables. Current liquidity is ability of a company to repay its short-term commitments by all the available current assets, including inventory and input value added tax.

For each type of liquidity there are recommended ratio, the excess of which indicates liquidity reserve. Taking into consideration that such current assets as receivables, inventory and input value added tax are directly related with ordinary business, and it is difficult to analyze them as investment resources to be invested in alternative projects in the short run, we take current and absolute liquidity as a basis for further calculations. We assume with good reason that:

1) difference between actual and statutory value of current liquidity ratio will represent a general reserve of liquidity;
2) all current assets, except for free cash, are assigned to ordinary business at least in the short term.

In addition, we also pay attention to the following points:

1. Reserve of absolute liquidity may be invested in any projects, including not related with enterprise activities.

2. Residual liquidity reserve, formed at the expense of such current assets as receivables, inventory and input value added tax, is to be primarily considered as investments in ordinary business.

Therefore, evaluating economic benefit from availability of liquidity reserve, we emphasize two components in its structure: 1) economic benefit from absolute liquidity reserve; 2) economic benefit from residual liquidity reserve. At the same time economic benefit from absolute liquidity reserve is appraised by us using an average index of alternative investment project profitability; economic benefit from residual liquidity reserve are evaluated using an index of enterprise ordinary business profitability.

Based on the arguments, mentioned above, we represent the model for calculating economic benefit from absolute liquidity reserve (Formula 1):

$$
E B_{a . l}=\left[\left(\frac{M R}{C L}\right)_{A}-\left(\frac{M R}{C L}\right)_{R}\right] \cdot C L \cdot\left(1+P_{a . i}\right)
$$

where $E B_{a . l}$ - economic benefit from absolute liquidity reserve, rub.;

$M R$ - cash of an enterprise, rub.;

$C L$ - current liabilities (current assets), rub.;

$P_{a . i}$ - average profitability of investments in alternative projects;

$A$ - actual value;

$R$ - recommended value.

The model of economic benefit from residual liquidity reserve is seen as follows (Formula 2).

$$
\begin{aligned}
E B_{p . l}=\left[\left(\frac{C A-M R}{C L}\right)_{A}-\left(\frac{C A-M R}{C L}\right)_{R}\right] & \\
& \cdot C L \cdot\left(1+P_{\text {m.a }}\right)
\end{aligned}
$$

where $E B_{p . l}$ - economic benefit from residual liquidity reserve, rub.;

$C A$ - current assets (working assets), rub.;

$P_{m \cdot a}$ - enterprise ordinary business profitability.

Then the general model of evaluation of economic benefit from liquidity reserve may be represented in the following manner (Formula 3).

$$
E B_{\text {a.l.r. }}=E B_{\text {a.l }}+E B_{p . l}
$$

where $E B_{\text {a.l.r. }}$ - economic benefit from liquidity reserve, rub.

By virtue of the Formula 3, subtracting liquidity reserve, we obtain growth of financial capital, defined by use of liquidity opportunity of a company (Formula 4). 


$$
\begin{aligned}
& \text { FFC }_{L}=\left[\left(\frac{M R}{C L}\right)_{A}-\left(\frac{M R}{C L}\right)_{R}\right] \cdot C L \cdot P_{a . i}+ \\
& +\left[\left(\frac{C A-M R}{C L}\right)_{A}-\left(\frac{C A-M R}{C L}\right)_{R}\right] \cdot C L \cdot P_{\text {m.a }}
\end{aligned}
$$

where $G F C_{L}$ - growth of financial capital, defined by use of liquidity opportunity of a company, rub.

\section{B. Methodology of assessment of economic benefit from reserve of borrowing capacity}

It makes sense to carry out assessment of borrowing capacity of a company by combining financial stability analysis and calculation of degree of financial leverage. On the basis of ratio of debt and own capital, which is an indicator of financial stability of an enterprise, it is possible to calculate borrowing capacity, which means additional possible amount of attracting debt capital without prejudice to financial stability of a company. In this regard it is necessary to compare recommended (statutory) value of the specified ratio with the actual value. However it is to be noted that increment of equity capital to profitability is provided up to a certain limit of debt capital compounding, where after following increase in debt financing leads to decrease in profitability of own funds. This rule is known as the concept of degree of financial leverage. Thus wise, for estimating borrowing capacity reserve of a company it is important to find a balance between the greatest possible approximation to the recommended (statutory) ratio of debt and own capital and ensuring a positive meaning of degree of financial leverage.

As can be seen from above, keeping in mind the recommended (statutory) values of ration of debt and equity capital, which is an indicator of financial stability of an enterprise, borrowing capacity is to be calculated according with this formula:

$$
B C=\left[\left(\frac{D C}{O C}\right)_{R}-\left(\frac{D C}{O C}\right)_{A}\right] \cdot O C
$$

where $B C$ - borrowing capacity of a company, rub.;

$D C$ - debt capital of a company, rub.;

$O C$ - own capital of a company, rub.;

$R$ - recommended value;

$A$ - actual value.

Degree of financial leverage under the recommended (statutory) ratio of debt and own capital may be calculated through the Formula 6, under the actual value - through the Formula 7.

$$
E F L_{R}=\left[\left(1-T R_{p}\right) \cdot(E P-A C I R)\right] \cdot\left(\frac{D C}{O C}\right)_{R}
$$

where $E F L_{R}$ - degree of financial leverage under the recommended (statutory) ratio of debt and equity capital; $T R p$ - profit tax rate;

$E P$ - economic profitability;

$A C I R$ - average computed interest rate.

$$
E F L_{A}=\left[\left(1-T R_{p}\right) \cdot(E P-A C I R)\right] \cdot\left(\frac{D C}{O C}\right)_{A}
$$

where $E F L_{A}$ - degree of financial leverage under the actual ratio of debt and equity capital.

It is obvious that the basis of taking a decision regarding compounding of debt capital should be fulfilment of the following conditions:

$$
\left\{\begin{array}{l}
E F L_{A}>0 \\
E F L_{R}>0 \\
E F L_{R}>E F L_{A}
\end{array}\right.
$$

The general model of evaluation of economic benefit from borrowing capacity reserve may be presented on the basis of the above calculations (Formula 9).

$$
E B_{\text {r.b.c.. }}=\left[1+E F L_{R}-E F L_{A}\right] \cdot O C
$$

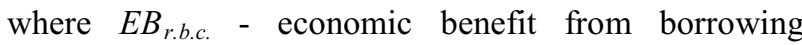
capacity, rub.

In accordance with the Formula 9, subtracting borrowing capacity reserve, we obtain growth of financial capital due to the use of debt capital of an enterprise (Formula 10).

$$
G F C_{D . C}=\left[E F L_{R}-E F L_{A}\right] \cdot O C
$$

where $G F C_{D . C}$ - growth of financial capital due to the use of debt capital of an enterprise, rub.

Summarizing the above methodology, we introduce the resulting models for assessing economic benefit of an enterprise from ownership and disposal of free financial capital (Formula 11), assessing the total finance capital growth due to the use of liquidity reserve and debt capacity (Formula 12) and assessing the total cost of financial capital (Formula 13).

$$
E B_{\text {f.f.c. }}=E B_{\text {a.l.r. }}+E B_{\text {r.b.c. }}
$$

where $E B_{\text {f.f.c. }}$ - economic benefit of an enterprise from the ownership and disposal of free financial capital, rub.

$$
\begin{aligned}
& G F C_{\text {Sum }}=G F C_{L}+G F C_{D . C}= \\
& =\left[\begin{array}{l}
{\left[\left(\frac{M R}{C L}\right)_{A}-\left(\frac{M R}{C L}\right)_{R}\right] \cdot C L \cdot P_{a . i}+} \\
\left.+\left[\left(\frac{C A-M R}{C L}\right)_{A}-\left(\frac{C A-M R}{C L}\right)_{R}\right] \cdot C L \cdot P_{m \cdot a}\right]+ \\
+\left[\left[\left(1-T R_{p}\right) \cdot(E P-A C I R)\right] \cdot\right] \\
\left.+\left[\left(\frac{D C}{O C}\right)_{R}-\left(\frac{D C}{O C}\right)_{A}\right] \cdot O C\right]
\end{array}\right.
\end{aligned}
$$

where $G F C_{\text {sum }}$ - the total growth of finance capital due to the use of liquidity reserve and debt capacity, rub. 
The total cost of financial capital, understood as economic benefit of an enterprise from ownership and disposal of its invested and free parts, is made up of two components:

1) an invested part of financial capital, calculated as net asset value based on the first part of balance sheet statement;

2) a free part of financial capital, which is calculated as the total growth of financial capital due to the use of liquidity reserve and borrowing capacity.

$$
C F C=N A V+G F C_{\text {Sum }}
$$

where $C F C$ - total cost of financial capital of an enterprise, rub.;

$N A V$ - net asset value of an enterprise, rub.

Summarizing the undertaken study, we draw attention to those results, which contain scientific novelty.

1. Essence of the notion of "cost of financial capital" is clarified. It is understood as economic benefit of an enterprise from ownership and disposition of its invested and free parts of financial capital. An outstanding feature of such an approach is account of economic benefit from ownership and disposal of its free part in financial capital cost, where this free part constitutes internal investment reserves, which are able to bring extra income to an enterprise.

2. The model of balance sheet statement of financial capital is suggested. It differs from the traditional balance sheet by a section "Economic benefit and reserves of financial capital", where assets include such indicators as economic benefit from liquidity reserve and economic benefit from reserve of borrowing capacity; at the same time liabilities have the figures of liquidity reserve and investment growth of finance capital.

3. The methodology for assessing economic benefit of liquidity reserve is elaborated. It allows considering potential income of an enterprise from possession and disposal of excessive stocks of working capital in value of financial capital.

4. The methodology for assessment of economic benefit from borrowing capacity reserve is developed. It allows taking into account potential income of a company from attracting debt capital in value of financial capital without any prejudice to financial stability of an enterprise and to profitability of own capital consumption.

5. The methodology for appraisal of enterprise financial capital is prepared. Its distinctive feature is a free part of financial capital, included in its body together with net asset value. This part is calculated as its total increment due to the use of liquidity reserve and borrowing capacity.

\section{Practical relevance}

The proposed methodology of appraisal of enterprise financial capital and its components may be used to solve such problems in management of industrial enterprise as determination of necessary volume of outward investments to be attracted (Formula 14) and determination of fair company take of outbound investor in firm value (Formula 15).

$$
I_{E}=I R-E B_{f . f . c .}=I R-E B_{\text {a.l.r. }}-E B_{\text {r.b.c. }}
$$

where $I_{E}$ - necessary volume of outward investments to be attracted, rub.;

$I R$ - total demand for investments, rub.

$$
S_{I}=\frac{I_{E}}{I_{E}+C F C}
$$

where $S_{I}$ - company take of outbound investor in firm value.

There should be carried out calculations by virtue of an application example, where results of evaluation, made by the proposed methodology, are to be compared with results of evaluation, made by the traditional approach (Table 2, 3).

Table 2. Comparative evaluation of necessary volume of outward investments to be attracted.

\begin{tabular}{|c|c|c|}
\hline \multirow{2}{*}{ Item } & \multicolumn{2}{|c|}{ Value } \\
\cline { 2 - 3 } & $\begin{array}{c}\text { Author's } \\
\text { methodology }\end{array}$ & $\begin{array}{c}\text { Traditional } \\
\text { approach }\end{array}$ \\
\hline $\begin{array}{c}\text { Total demand for } \\
\text { investments, rub. }\end{array}$ & 4000000 & 4000000 \\
\hline $\begin{array}{c}\text { Economic benefit } \\
\text { from liquidity } \\
\text { reserve, rub. }\end{array}$ & 800000 & - \\
\hline $\begin{array}{c}\text { Economic benefit } \\
\text { from borrowing } \\
\text { capacity reserve, } \\
\text { rub. }\end{array}$ & 1500000 & - \\
\hline $\begin{array}{c}\text { Necessary volume of } \\
\text { outward investments } \\
\text { to be attracted, rub. }\end{array}$ & 1700000 & 4000000 \\
\hline
\end{tabular}

Table 3. Comparative evaluation of company take of outbound investor in firm value.

\begin{tabular}{|c|c|c|}
\hline \multirow{2}{*}{ Item } & \multicolumn{2}{|c|}{ Value } \\
\cline { 2 - 3 } & $\begin{array}{c}\text { Author's } \\
\text { methodology }\end{array}$ & $\begin{array}{c}\text { Traditional } \\
\text { approach }\end{array}$ \\
\hline Net asset value, rub. & 3000000 & 3000000 \\
\hline $\begin{array}{c}\text { Growth of financial } \\
\text { capital due to the use } \\
\text { of liquidity reserve, } \\
\text { rub. }\end{array}$ & 500000 & - \\
\hline $\begin{array}{c}\text { Growth of financial } \\
\text { capital due to the use } \\
\text { of borrowing capacity } \\
\text { of a company, rub. }\end{array}$ & 1000000 & - \\
\hline $\begin{array}{c}\text { Cost of enterprise } \\
\text { financial value, rub. }\end{array}$ & 4500000 & 3000000 \\
\hline $\begin{array}{c}\text { Necessary volume of } \\
\text { outward investments } \\
\text { to be attracted, rub. } \\
\text { (Table 2) }\end{array}$ & 1700000 & 4000000 \\
\hline $\begin{array}{c}\text { Company take of } \\
\text { outbound investor in } \\
\text { firm value }\end{array}$ & 0,27 & 0,57 \\
\hline
\end{tabular}


Comparing results of the Table 2, we can see that necessary volume of outward investments to be attracted, calculated by the author's methodology, is 2.3 times less than that one, which is calculated by the traditional approach. The difference is due to the use of internal investment opportunities of an enterprise. The comparison results on the basis of the Table 3 show that under the author's technique company take of outbound investor in firm value is reduced by 2.1 times that indicates reducing risk of corporate property dissemination.

\section{Conclusions}

The results of this study confirm dependence of value of investment potential of industrial enterprises on an applied methodology for assessing cost of financial capital. The traditional approach to financial capital cost appraisal does not include internal investment reserves of an enterprise, such as liquidity and borrowing capacity reserve, leading to overestimation of expected needs in outward investment to be attracted. The author's methodology for appraisal of financial capital value under solving problems of determination of required outward investments volume to be attracted and determination of fair value of company take of outbound investor in firm value promotes to detect and to use internal investment opportunities and decrease dependence on external financing. This contributes to minimize risk of corporate property dissemination without compromising development of industrial enterprises. Timely detection and use of liquidity reserve allows improving efficiency of enterprise working capital management, providing increase in its economic efficiency. Sustainable use of borrowing capacity reserve without compromising profitability of own capital and without possibility of financial stability loss is also aimed at expanding investment opportunities in the best interests of industrial enterprise development.

We are grateful to the sponsors for the opportunity to participate in the conference and to publish the piece. The work was supported by Act 211 Government of the Russian Federation, contract № 02.A03.21.0011.

\section{References}

1. A. Black, Questions of Value (ZAO "OLIMPBISNESS", Moscow, 2009)

2. A. Gershun, M. Gorskii, Balanced Control Technology (Publishing house ZAO OLIMPBISNESS, Moscow, 2006)

3. A.N. Sorokin, Problems of improving the organization of production and management of industrial enterprises, 1, 204-208 (2012)

4. S. Beer, Brain of The Firm (Editorial URSS, Moscow, 2005)

5. D.L. Volkov, The Theory of Value-based Management: Financial and Accounting Aspects
(Publishing "Vysshaia Shkola Menedzhmenta", St. Petersburg, 2008)

6. E.I. Tarasevich, Valuation of Real Estate (SPbGTU, St. Petersburg, 2007)

7. Gerard A. Cahill, George P. Schneider, Problems of management theory and practice, 5, 92-95 (1998)

8. I.V. Nikitushkina, Company Cost Management. vol. 1 (Delovaia i Professionalnaia Literatura, Moscow, 2008)

9. J.P. Aniskin. Financial Activity and Value of The Company: Planning Aspects (Omega-L, Moscow, 2005)

10. Jay E. Fishman, Shannon P. Pratt, J. Clifford Griffith, Kate Wilson, Guideline for Business Value Appraisal (ZAO KVINO-KONSALTING, Moscow, 2000)

11. Hahn Dietger, Hungenberg Harald. PuK. Wertorientierte Controllingkonzepte (Finansy i Statisika, Moscow, 2005)

12. M.I. Cherutova, I.G. Trofimova., O.V. Cherutova, Proceedings of the Bratsk State University. Ser.: Economies Andes Management, 1, 153-160 (2013)

13. M.V. Kudina, The Theory of Company Value (Publishing house Forum: INFRA-M, Moscow, 2010)

14. O. Chernozub, Life after Crisis: Cost-based Approach to Management of The Private Company (Alpina Publisher, Moscow, 2009)

15. P.A. Drogovoz, Management of Innovation Industrial Enterprise Value (Publishing house MSTU n.a. N.E. Bauman, Moscow, 2007)

16. S.V. Gribovskii, E.N. Ivanova, D.S. Lvov, O.E. Medvedeva, Assessed Value of Real State (INTERREKLAMA, Moscow, 2003)

17. S.V. Valdaizev, Business Valuation: 2-d ed., updated and revised (TK Velbi, Publishing house Prospekt, Moscow, 2006)

18. V.A. Varfolomeeva, N.A. Ivanova, I.I. Arkhipova, Actual Problems of Economics and Management, 3(3), 3-11 (2014)

19. V.A. Shcherbakov, N.A. Shcherbakova, Valuation of Enterprise (Business) Cost (Omega-L, Moscow, 2006)

20. V.E. Esipov, G.A. Makhovikova, S.K. Mirzazhanov, Business Appraisal: Complete Practical Guide (Eksmo, Moscow, 2008)

21. V.E. Esipov, G.A. Makhovikova, V.V. Terekhova, Business Appraisal (Piter, St. Petersburg, 2003)

22. V.M. Rutgaizer, Business Value Appraisal. Teaching medium (Moscow, Maroseika, 2007).

23. V.V. Zarev, Assessment of Business Value. Theory and Methodology (IUNITI-DANA, Moscow, 2007) 